\title{
Nima Yushij's Phoenix: From Romanticism to the First Modern Persian Poetry
}

\author{
Muhammad Hussein Oroskhan \\ Department of English Literature, Faculty of Foreign Languages, Shiraz University, Shiraz, Fars, Iran \\ Elham Mahmoudi \\ Department of English Literature, Faculty of Foreign Languages, Yazd University, Yazd, Iran
}

\begin{abstract}
The beginning of twentieth century is marked by the Constitutional Revolution in Iran. Alongside the revolution, sweeping changes were brought about in every aspects of Iranian society. Undeniably, these extensive changes affected the literature of time. With respect to Persian poetry, Nima Yushij stamped a new pattern on Persian poetry and released it from its long-standing tradition. The plausible reason explaining Yushij's innovation has remained an enigma for literary scholars. Nonetheless, Yushij's attachment to Romanticism can be analyzed to clarify the ambiguous realm behind Yushij's big step for the modernization of Persian poetry. As such, Morse Peckham's theory of Romanticism which is subdivided into four consecutive stages is recruited to encapsulate Yushij's progress in Romanticism. Studying Yushij with respect to these stages proves that Yushij's Phoenix previously dismissed as a romantic poem is indeed Yushij's culmination of Romanticism. Eventually, this is concluded that Yushij reaching the pinnacle of Romanticism in Phoenix has been a decisive factor in creating a new path for Persian poetry.
\end{abstract}

Index Terms - modern Persian poetry, romanticism, Nima Yushij, Peckham, phoenix

\section{INTRODUCTION}

A sudden flare exploded and hit the mid-eighteenth century Europe. It wasn't a war, a piece of technology or a political event; however, it was the birth of a new set of ideas which were listed under the rubric of romanticism in the works of artist and philosophers. Romanticism began his long journey from Europe and subsequently spread all over the world. Europe can exult in his son forever as it is wildly known that "Romanticism was a European cultural movement, or set of kindred movements" (Ferber, 2005, p.10). Nonetheless it took some years when the title romanticism was officially set for this movement: "what came to be called the Romantic period emerged as an object of academic study in the universities of Western Europe and North America during the later nineteenth century" (Lindenberger, 2009, p.46). This blinding flash had an everlasting impact upon the Europe's view of the world with respect to nature, children, love, sex etc.

Without the slightest doubts, Europe had become the center of romanticism ideologies because it had some historical backgrounds which facilitated its commencement. Similar historical backgrounds may also occur somewhere else and lay the foundation for romantic ideas to be promoted: "The historical conditions that gave rise to Romanticism are still with us. So why would it be surprising that contemporary world writers look toward the techniques of Wordsworth, Keats, and others leading Romantics?" (Black, 2014, p.1). As such, it is no surprising to follow the trace of romanticism in any other place around the world. One of the places that romanticism found its bedrock to develop was in Iran. Indeed modern Persian poetry owns its flowering to the contribution of romantic new ideas otherwise it was still coping with the old tradition of Persian prosody.

Likewise, Romanticism began to unfold its context in Iranian contemporary literature with a gap of one hundred and fifty years as compared with the beginning of romanticism in Europe. To this point, "Nima Yushij, the father of modern Persian poetry in contemporary Iran" (Oroskhan, 2016, p.52), has always been at the focal point of Romanticism investigation in Iran: "Yushij's romanticism represents the culmination of romanticism in Persian literary history" (Jaffari, 2007, p.200). Within this context, critics have demonstrated varying romantic discussions with regard to Yushij's early poems:

Yushij's most prominent romantic poems are named as Tale of Pallid Color, Legend and Oh Night!. Yushij wrote these poems between 1919 and 1921. Yushij's tendency toward romanticism is shown until 1930. Altogether, this could be concluded that Yushij's tendency toward romanticism is wrapped in this period of ten years (Jaffari, 2007, p.200).

However, the debate over Yushij's romanticism is never limited to this period of ten years. Indeed, Yushij's real romanticism is flourished after this period of his writing in a poem entitled Phoenix. In support of this argument, Morse Peckham's theory of Romanticism is recruited to place new perspective upon Yushij's Phoenix. Therefore, through this paper, it is tried to show how Yushij's earlier romantic poems follow Peckham's stages of Romanticism and moreover concludes that Yushij's Phoenix matches with Peckham's last stage of Romanticism which is Stylism. As such, Yushij's 
Phoenix previously considered a non-romantic poem is shown as the Yushij's culmination of Romanticism and thus a justifiable reason for becoming the first modern Persian poetry.

\section{PeCKham's Theory of Romanticism}

For the first time, at the end of nineteenth century, "the term Romanticism began to attract attention from different academic places around the world" (Lindenberger, 2009, p.17). Though in terms of history, Romanticism just refers to a short period of time in history; yet a clear and precise definition was never provided for the term "Romanticism". As such, it is no surprising to see how Edwin Berry Burgum is describing academicians' efforts to define the concept of romanticism as "a hazardous occupation which has claimed many victims" (1941, p.479). Burgum has the right on his side to assert such a bold claim as there so many contradictory definitions surrounding the concept of "Romanticism". Indeed the main problem lies in the absence of any cohesive definition which can encompass the whole range of different ideas of prominent romantic figures. In this respect, one definition per se cannot cover the views of other romantic writers; therefore, achieving a unified definition of romanticism has become impossible.

However, Morse Peckham (1914-1993) seems to have achieved an encompassing definition of the term "Romanticism", even though, his definition may not be necessarily a unified definition of the term. Peckham arduously tries to determine his train of thoughts regarding the concept of Romanticism. Indeed he improves himself and simultaneously upgrades himself to a level to stand on an acceptable platform for formulating the essential concept of Romanticism. Eventually, he achieves his desirable end by writing his last article entitled "The Dilemma of a Century: The Four Stages of Romanticism".

Peckham's primary purpose is to avoid the sources of ambiguity about Romanticism by clearly determining some basic concepts. He first declares that romantics "had arrived at a way of viewing the world which was profoundly different from any world-view that had ever appeared before"(2009, p.7). Seemingly, Peckham mentions nothing special about the concept of Romanticism; however, he raises a subtle point behind this view by indicating that each "profound cultural change is the emergence of new social roles" (2009, p.7) and more importantly the essence of the new role given to romanticism is that " it was an anti-role and that it was designed to symbolize the difference between role and self" (2009, p.8).

The main reason that Romanticism is distinguished from other schools of thought lies at this very specific point. Prior to Romanticism, any school of thought believed that self should play a given role addressed to the self as the self was never being distinguished from its role-playing. In essence, whenever a new school of thought appears the self plays a different role with regard to new school of thought. Nonetheless, the romantics did play roles but not for performing a specific action but " for the sake of isolating what they called the Self, the sense of identity, the only subjectively perceived quality of experience common to the playing of all roles" (2009, p.9). At this juncture, what Peckahm indicates about Romanticism is "to create an anti-role, a role that was different from all other roles in that it could not be integrated into the social structure of interlocking roles" (2009, p.9).

As such, Romanticism never fails to notice its biggest problem which is defining the essence of self per se considering human's desire for external world and its subsequent desire for achieving meaning and value. Such a radical breakthrough leads also to some undesirable consequences or a time when the "mind was sundered from nature, Subject from Object, the Self from the role, which was seen at best as the means of realizing the Self, and at worst, as the instrument whereby nature violated the Self" (2009, p.11). Romantic's innovative view of the world produces abnormal situation out of previous normal situations. Previously, everything bore at least a kernel of meaning and value due to its attachment to external world, nonetheless, romantics had to "experience a sense of profound isolation within the world and an equally terrifying alienation from society" (2009, p.11). Accordingly, finding a way to express and symbolize this sense of created isolation and alienation became their major task due to their unique perspective toward the self.

Peckham tries to find a way out of this theoretical impasse in which the whole romantic ideas are finally cohered. His first step is to reach a firm ground to set his definition of Romanticism perceiving its alienated and isolated condition. For achieving this aim, Peckham defines four stages for the concept of Romanticism and how each stage is put forward to complete the previous one. The he put forward four stages: "To the discovery of that ground there can be discerned, I believe, four stages" (2009, p.17). The main reason behind Peckham's unique perspective is his attitude toward reality derived from Hegel's view of subject and object: "Reality, then, is what mind has done to world and what world has done to mind. Reality is history, the history of how, in its dealings with the phenomenal world" (2009, p.16).

Peckham's first stage of Romanticism is "Analogism". He cites analogism as the first stage of Romanticism as it is the feature of which the lengthiest discussion is generated. For Peckham, analogism "depends upon a particular mode of perceiving, or more properly, of interpreting, the world, particularly the natural world" (2009, p.17), on the other hand, it can be simply defined as nature worship which is commonly affiliated with the beginning of the concept of Romanticism. Peckham elaborates on this stage as following:

Instead of being the model for all other experience, it became a unique, superior, transcendent mode of experience, to be achieved only after long preparation, great difficulty, and profound introspection. Instead of leading to successful role-playing, Romantic nature worship was designed to lead away from any roleplaying at all $(2009$, p.17). 
Peckham believes that the romantics pioneer conveyed their view through this attitude, yet, this view had its own disadvantages. The interaction between subject and object is reduced to a mere one-way subject relation as the object is reduced to a mere transparent notion: "It deprived the Object of all substance, turning it into a mere transparency. This was unsatisfactory, for one of the basic determinations of Romanticism was to meet reality head-on" (2009, p.18). Analogism can assume cardinal importance as it provides a ground for studying Romanticism and interpreting its meaning, nonetheless, it reaches a deadlock over the notion of reality. As it was previously discussed, reality focuses on the interaction between the subject and the object and deriving from this interaction is the consequent need to action: "Analogism offered a ground for value, but no imperative to act. And without action, reality could not be encountered and the Self could not be realized" (2009, p.18).

Peckham's second stage of Romanticism is Transcendentalism. This notion is followed after analogism to resolve the impasse of analogism by focusing on the interaction between the subject and the object. The stage of Transcendentalism begins by ripping the world of any ground or value and concentrates on the power of self to create a categorical statement about ground, meaning and value:

Transcendentalism deprived the world wholly of value, turned it once again into a meaningless chaos, but preserved the Self and gave the Self's drive for meaning, order, value, and identity a divine authority. This is the heroic, world-redemptive stage of Romanticism. (2009, p.19)

Transcendentalism encompasses the notion Virtuoso. In this respect, "Transcendental Virtuoso, as we have seen, adopted a social role and pushed it beyond the point that existent society could achieve" (2009, p.19). The supposed hero severs his connection with the world and aims his attention at the essence of the self to survive and continues to live in this world, nevertheless, the stage of Transcendentalism also encounters some difficulties. At the first glance, it seems to correct the defect of analogism which was the absence of any interaction between the subject and the object by focusing on the power of the subject to create a connection with the object; still it suffers from a defect because: "it has placed the Transcendental hero in the position of imposing his will upon other human beings.... But the Romantic cannot violate another person." (2009, p.19). Though, Transcendentalism resolves analogism's defect about interactional relation between the subject and the object to create reality, it carries another defect which is the sense of introducing one model as the one and only model for the whole world otherwise the world may lead to evil purposes:

If the Transcendental hero sets up a morality and imposes it upon others for the sake of revealing and realizing the Self, it makes no difference, really, what that morality is; it can perfectly well be an evil and tyrannous morality, if it does the job for him (2009, p.20).

As such, Romanticism cannot accord positive value to this radical notion of Transcendentalism. Therefore, Peckham believes that the third stage of Romanticism as Objectivism is introduced to complete Transcendentalism. This stage follows the path of Transcendentalism with a big difference. It views not the Transcendentalism's one path of achieving the desirable interaction between the subject and the object as the only path of accomplishing the desirable aim whereas for the objectivist:

All metaphysics, all moral systems, are not even human instruments for realizing value; they are at best human instruments for dealing with the world, for staying alive, but in themselves they provide no imperative to action, no imperative to duty, no imperative to morality, no imperative to world-redemption, for the world cannot be redeemed: any scheme for redemption is but another illusion (2009, p.20-21).

Objectivists solve the negative side of Transcendentalism by considering the interaction between the subject and the object as only a period of time dedicated to coping with the world and surviving in it. Even they propose death as a solution which makes all these efforts valuable: "Objectivist says, the only perfect order is death. Life, and value, then, lie in the pure encounter of Self and Object, of Subject and reality, without illusions" (2009, p.20). Seemingly, Objectivists have solved the negative aspect of Transcendentalism; yet, they have encountered some bigger problems by proposing death to be the possible solution as "it deprived the individual of any imperative to action" (2009, p.22).

Needless to say that the inevitable consequence of Objectivist is complete despair and discouragement to take any action as "the only action possible is description, and that is done in heroic despair" (2009, p.22). This perspective also has a certain negative side which is impossible to be overlooked. Therefore, the last stage of Romanticism that is believed to solve the problem is introduced: "The next, and in the nineteenth century the final, stage of Romanticism solved all of these problems. It was the stage traditionally called Aestheticism, but which I prefer to call Stylism" (2009, p.22). Stylism provides the most desirable ground for the individual to work on and survive as it both provides a ground and an imperative to action lacking in the previous stages. Altogether, Peckham defines it as follows:

Stylism is, therefore, the perfect way of symbolizing the sense of order and value and meaning without tempting him to impose that pattern upon reality. It even to a certain extent permitted him to solve the problem of the imperative to action, for it gave him an imperative, if not to act upon the world, at least to create a unique style which, as it was perfected, offered him a new and richer gratification of the drive to order and value, and therefore a promise of greater gratification. (2009, p.22)

\section{NIMA YUSHIJ'S ROMANTICISM}


Between 1905 and 1911, Iranian society began to change and shift away from its traditional history toward some new and broader perspectives which finally led to Constitutional Revolution. Step by step a new society was formed as it is discussed in The Economic History of Iran:

In spite of the dominance of feudalism, objective conditions furthered the development of an internal, common, national .... market. This process was accustomed by the impoverishment of the peasants, the ruin of the small producers, the development of market and monetary relationships in the country, and the specialization of various regions. (1971, p.44)

Iranian society is pushed toward modernization by the impact of new thoughts exerted from outside of Iran and people's attempt to instill the same views within the traditional structures. Expecting these changes to be only confined to sociopolitical situations of the time is not approvable; moreover, innovative ideas reach far beyond the economic and societal boundaries and encountered the literary inheritance of Persian language. Likewise, innovative literary ideas began to transform the stagnant reservoir of Classical Persian literature alongside all these diverse social developments. Within the new path of literary change, two different views collided:

First, that of the reformists, led by the well-known poet Bahar (1886-1951), who published a literary magazine called, "Daneshkadeh" (The House of Knowledge), and organized a literary circle by the same name in Tehran; and second, that of the radicals led by Taghi Raf'at who was the editor of a literary magazine called "Tajaddod". (Nafisi, 1997, p.9)

Each poet of the time was lined up before each of these main literary views and the two opposing poles were keeping the wheels of literary modernization in Iran. The major talking point of these two literary circles was to define a new literary discourse for Persian poetry and release it from the traditional literary bonds seriously hindered Persian poetry to produce its first modernized blossom. Unexpectedly, the poet who ignited the first spark of modernization in Persian poetry never belonged to any of these two groups; today who bears the title of "Father of Modern Persian poetry" (Oroskhan, 2016, p.52) is Nima Yushij (1895-1960). He was born in 1895 in Yush near Mazandaran province. He introduces himself in one of his letter in this way:

My early life was spent among herdsman and horse breeders, who in search of meadows, migrate between distant summering and wintering grounds, and at night, get together for long hours around the campfire in the mountains. From my whole childhood period I remember nothing but wild wrangles and things related to nomadic life and their simple recreation in monotonous, blind, and ignorant tranquility. (Yushij, 1984, p. 31)

What distinguished Yushij from other poets is exactly his tendency toward the natural world as opposed to the educational systems which the two literary groups boasted about. In one of his letters to his brother, he expresses his wishes to return to nature:

When I heard the jingling of the goat kids, when the sun cast a shadow in the valleys, my dear everywhere I was thinking of you and how we had been together so many times in these places. Now we are miles apart from each other. You have become captive to the tumult of the jama'at and I to the confines of the city walls. Whenever I think of this way of life, how can I not become depressed?

Yushij as a solitary figure confronted the millennium history of Persian poetry that was remained untouched. Yushij truly succeeded in creating a new perspective in Persian poetry not by pursuing an elaborate educational system whereas he captured a fleeting moment that has hit the Europe some years before. Yushij captured the essence of Romanticism in his works, indeed "Yushij's romanticism represents the culmination of romanticism in Persian literary history (Jaffari, 2007, p.200)". Majid Nafisi in Modernism and Ideology in Persian Literature: A Return to Nature in the Poetry of Nima Yushij declares that "the question as to what elements influenced Yushij to take a step forward and break the yoke of classical metrics still needs to be investigated" (51). Assuredly, Yushij's romanticism can be considered as a decisive factor in influencing him to change the direction of Persian poetry. As such, through the rest of this paper it is tried to investigate Peckham's four stages of Romanticism in Yushij 's works with specific attention to Phoenix which is the first modern Persian poetry.

Yushij's early poems have always been at the center of Romanticism investigation in Iran. These poems carry some prominent features of Romanticism. Tale of Pallid Color is Yushij's first long poem which is written one year before Legend (Afsaneh) in 1920. The poem's main motif is Yushij's nostalgia for his birthplace and therefore is the expression of Yushij 's admiration for countryside and his strong aversion for the cities:

I am not one of these lowly people of the city

I am the painful memory of the mountain people

It was bad luck that brought me to your city

And I have been suffering ever since

I am happy with the mountain life

I've grown accustomed to it from childhood

Oh, how lovely is my homeland

It is far from the reach of city folk

There is no pretension there, no adornment

No fetters, no cheating or treachery

How lovely is the fire on dark nights 
Alongside the sheep on the hillside. (Yushij, 1992, p.26)

Yushij's Tale of Pallid Color clearly expresses Peckham's first stage of Romanticism which is Analogism. In this stage, the artist in search of a ground for value takes refuge in nature and instead of role-playing the subject dissolves him/her self in nature and tries to free himself from any social human structure. At the same time the subject distances himself so much from the object that the self is seen through nature and just experience the nature instead of taking any action.

Yushij's second important poem is Legend (Afsaneh) which is written in the form of a dialogue between a lover and Afsaneh. Yushij's Romanticism takes a new form in Legend which presents this poem as a unique poem. Indeed, Yushij's Legend is "his most distinguished poem with regard to features of romanticism"(Jaffari, 2007, p.237). (Legend) Afsaneh in Farsi is used as a name for girls and its root which is "afsun" means to cast a spell on someone. Through the poem, the lover bitterly and repeatedly complains to Afsaneh:

Oh Afsaneh, Afsaneh, Afsaneh,

I am the target of your arrows

Oh, remedy of the heart, medicine for pain

For my nocturnal cries

What do you mean to do with me, so scourged?

And what are you, you hidden from my views. (Yushij, 1992, p.42)

The mentioned part shows lover's ambiguity in recognizing the true nature of Afsaneh. The lover tries to comprehend the concept of love through his interaction with Afsaneh; nevertheless, he is absolutely incapable of doing such a task. Even in some parts of the poem Afsaneh claims to be unrecognizable and introduces herself in this way:

Oh there were so many dreadful nights

When from behind the cloud appeared

A figure you did not recognized

In a sad heart rendering voice

It whispered my name in the depths of your ears

I am that same stranger, O lover!

That voice which rises from the heart

I am the face of the worlds dead

I am an instant that flares as lightening

I am a warm tear melting in some eye (Yushij, 1992, p.49)

Lover's incapability in recognizing Afsaneh who is the embodiment of the notion of love and even Afsaneh's claim of being unrecognizable compels the lover to perform the role of a transcendental hero. The role of transcendental hero put a distance between the hero and the society and makes hero unique in pursuing his ambition. Likewise, the lover takes the role of transcendental hero and pushes all other notions of love aside by even attacking Hafez: "'O Hafez! What lie and deceit in this, Spoken by the tongue of the wine, the goblet, and the cup-bearers" (65). Hafez is one of the classical Persian poets whose poems are still the most read poems among the Iranians in such a case that Dick Davis has pointed that Iranian households can be found without a Quran but never without a Hafez's Divan (2013, 5). Undoubtedly, Hafez's stature is endowed with a great stature among the Iranians along all these years. Therefore, lover's attacking of Hafez can clearly shows his rejection of the value of the society and its conception of the notion of love by trying to find a new path for himself: "Oh come forth from this narrow vale/ for it is the shepherd's best resting place/ for no one knows the way here/ so here, where everything is alone/ we may sing together (Yushij, 1992, p.71)". As it is shown, finally the lover taking the role of a transcendental hero and rejecting the society tries to build his notion of reality by distancing himself from other people.

In the consequence of Yushij's most romantic poems, Oh Night! is the last poem which is written just a couple of months after Legend. In Oh Night!, as it is self-explanatory, Yushij is addressing a gloomy and dark night. The poem shows the third stage of Peckham's Romanticism, Objectivism. Through this stage, alienation has extended through every aspects of the individual and compels him to see death as the solely perfect order giving meaning to this meaningless world. In the same respect, after a long bittering conversation with the night, Yushij ends his poem in this way:

Oh night, how long shall I look upon thee?

Let Sleep falls upon my eyes.

From a society so gloomy.

A moment less I remember

And...

Free of any Afsaneh

Let my eyes be closed

Less the world laughs at me (Yushij, 1992, p.34)

Masoud Jaffari in his monumental work entitled From Constitutional Revolution to Nima Yushij attempts to summarize his view of Yushij's Romanticism in this way: "Yushij's most prominent romantic poems are named as Tale of Pallid Color, Legend and Oh Night!" (2007, p.200). He specifically mentions that "Yushij's tendency toward 
romanticism is wrapped in this period of ten years" (2007, p.200). Also other critics ${ }^{1}$ concur with Jaffari that Yushij's Romanticism ends with Oh Night! and afterwards Yushij highly tends toward realism and symbolism and never returns back to Romanticism again. Through a closer reading, this can be revealed that Yushij's Romanticism never ends with Oh Night! whereas it actually comes out in full blossom in Phoenix ${ }^{2}$ which is highly believed to a realist and symbolist poem by the Iranian literary scholar ${ }^{3}$. Masi Haiva, Yushij's scholar, believes that Yushij's real breakthrough is achieved in Phoenix because "Phoenix achieves an absolute liberation from Old Persian prosody and the culmination of the project that Legend never accomplished (Mashi, 2013, p.53). As such the status of Phoenix is highly appreciated in Persian poetry as it is marked with beginning of modern Persian poetry. Drawing particular attention to Phoenix, this could be deduced that Phoenix is indeed the culmination of Yushij's Romanticism which is Stylism.

Stylism is the last stage of Romanticism that tries to break the impasse of objectivism. It is indeed used to symbolize the sense of value non-existent in life and provide a defense against the hell of existence. To achieve this aim, Yushij creates the symbol of phoenix to both avoid the valueless world and simultaneously establish a unique style in Persian poetry.

The Phoenix, the bird of sweet songs, the world's renown

Is left homeless by the blow of cold winds

Upon the sticks of reeds

She sits alone

Round her on every bough a bird.....

Flattering suddenly on the spot

She gives a cry bitter and pathetic

Whose meaning not any passing bird know

Inebriate then on her inner anguish

Throw herself upon the awe of the fire

Blows a sharp wind, the bird is burnt!

The ash of her body, the bird has saved

Then her chicks come out of her ash" (Yushij, 1992, p.438)

The burning of phoenix and the birth of her children shows Yushij's step toward the last stage of romanticism which is Stylism. Yushij rose in a high status by writing phoenix. Undeniably, Yushij's Phoenix has exerted an enormous impact upon the Persian poetry that has laid the foundation of modern Persian poetry (Langroudi, 1999). This lasting influence has always been discussed in terms of its poetic language and the process of its successful innovation; nonetheless, no one has investigated these poems in terms of its content and how the content has contributed to the formulation of a new form. In this sense, Yushij has culminated his Romanticism by writing Phoenix. This can be concluded that he may not have resolved the valueless world, yet he has truly created a new style to deal with this world.

\section{CONCLUSION}

The beginning of twentieth century is marked with the Constitutional Revolution and its considerable impact upon each and every aspect of society. Undoubtedly, these changes were even extending to literary works. Following the route of modernization in Persian poetry, one reaches Nima Yushij who wrote the first Persian modern poem. Among all the writers of time what helped Yushij to achieve this end has been remained unexplained. However, through this paper it was tried to demonstrate that Yushij's successful passage of different stages of Romanticism has greatly inspired Yushij in creating a new path for Persian poetry. Romanticism refers to a short period of time in history, yet it has been the most ambiguous era for literary historian. For some, reaching a cohesive notion of romanticism has been an impossible task to be accomplished. The existence of diverse meanings has greatly hindered this progress toward a unified meaning about Romanticism. Nonetheless, Peckham's framework of Romanticism reveals certain puzzling features beneath the concept of Romanticism by placing it in a new platform. He constitutes the belief that romanticism evades role-playing for the sake of distinguishing the self. To this end, Romanticism is experiences passing through different stages for achieving this aim. These stages are analogism, Transcendentalism, Objectivism and Stylism. As it was shown, Yushij successfully passes through these stages and by the last stage; he creates a new path for Persian poetry in his Phoenix.

\footnotetext{
${ }^{1}$ Masih Heiva also in his prominent book, A Dictionary of Modern Persian Poetry: Nima Yushij holds the same view about Yushij's Romanticism with respect to Tale of Pallid Color and Legend.

${ }^{2}$ Phoenix is a magic bird which is said to live for one thousand year. And when such a long time is passed, she would die. She would collect and cut her own firewood and then would sit above it and sings her songs until she becomes intoxicated and flaps his wings vigorously. At this moment, she catches fire and is burnt to death and from her ashes; a testicle is created which lacks any mate and later a new Phoenix is born. This process is continued once in each thousand years (Masih, 281).

${ }^{3}$ Masih Heiva in A Dictionary of Modern Persian Poetry: Nima Yushij and Majid Nafisi in Modernism and Ideology in Persian Literature: A Return to Nature in Poetry of Nima Yushij declares this view regarding Yushij's Modernism and Ideology in Persian Literature: A Return to Nature in the Poetry of Nima Yushij.
} 


\section{REFERENCES}

[1] Abdullaev. Z.Z, (1971). The Economic History of Iran, University of Chicago: Chicago Press, 44, Print.

[2] Black, W. (2014). The Persistence of Romanticism in World Literature, World Literature Today. Retrieved January, 2014 from https://www.worldliteraturetoday.org/2014/january/persistence-romanticism-world-literature-william-black.

[3] Burgum, B. E. (1941). Romanticism. The Kenyon Review, Vol. 3, No. 4, pp. 479-490. Retrieved Autumn, 1941, from http://www.jstor.org/stable/4332291.

[4] Davis, D. (2013). Hafez; Jahan Malek Khatun; Obayd-e Zakani. Faces of Love: Hafez and the Poets of Shiraz. United States: Penguin Group.

[5] Ferber, M. (2005). A Companion to European Romanticism, London: Blackwell Publishing Ltd.

[6] Ja'fari, M. (2007). From Constitutional Revolution to Nima Yushij. Tehran: Nashre-e Markaz.

[7] Lindenberger, H. (2009). Theories of Romanticism: From a Theory of Genre to the Genre of Theory, Essays in Romanticism. 17: 27-51. doi: 10.3828/EIR.17.1.2.

[8] Langeroodi, Sh. (1998). An Analytic History of Persian Modern Poetry (4 Volumes), Tehran: Markaz Publication.

[9] Masih, H. (2013). A Dictionary of Modern Persian Poetry: Nima Yushij. Tehran: Doostan,

[10] Naficy, M. (1997). Modernism and Ideology in Persian Literature: a Return to Nature in the Poetry of Nima Yushij, Maryland: University Press of America, Print.

[11] Oroskhan, M. H. (2016). Following the Trace of Byronic Hero in Yushij's Afsaneh, Epiphany: Journal of Transdisciplinary Studies, Vol. 9, No. 1. doi: 10.21533/epiphany.v9i1.202.

[12] Peckham Morse. (2009). The Dilemma of a Century: The Four Stages of Romanticism, Essays in Romanticism, Vol. 17, No. 1, pp. 7-26, Print. doi: 10.3828/EIR.17.1.1.

[13] Yushij, N. (1992). Majmu'e-ye Kamel-e Ash'ar Nima Yushij: Farsi va Tabari, Tehran: Negah Publication, Print.

[14] Yushij, N. (1984). Nameha-ye Nima Yushij, Sirus Tahbaz, ed., Tehran: Nashr-e abi, Print.

Muhammad Hussein Oroskhan: He is currently a PhD candidate at Shiraz University. He has already published a couple of articles in Persian Literature. His main field of interest includes Comparative literature with respect to the perception of American literature in Persian literature considering the political tension of these two countries in recent years.

Elham Mahmoudi: She has just finished her B.A form Yazd University. She is looking forward to applying for one of the prestigious Universities in France in near future to continue her studies in the field of Comparative literature. 